\title{
Digital ruble in Russian civil circulation: challenges and perspectives
}

\author{
Andrey V. Stepanchenko* \\ Ural State Law University, Ekaterinburg, Russia
}

\begin{abstract}
Recently, Russia, as well as the whole world, has undergone changes in the payment market, along with cash funds, cashless methods of paying for goods and services, payments and transfers. Despite this, the demand of market participants for increasing the speed, convenience and security of cashless payments and transfers, as well as a decrease in bank commissions, is constantly growing. In order to facilitate the digitalization of the financial market, the Bank of Russia is already implementing such infrastructure projects as the Fast Payment System, the Unified Biometric System, the Digital Profile, the Know Your Client platform and is actively exploring the possibility of introducing a digital national currency. In 2019, the Bank of Russia prepared the first report - a study on the prospects for digital currencies of central banks, and in 2020 it published a report for public consultations "Digital Ruble". Taking into account the results of public discussion of this document, in April 2021 the Bank of Russia presented the Concept of the Digital Ruble, in which it presented the features of the implementation of the target model of the digital ruble. The paper is devoted to the analysis of the Concept of the Digital Ruble proposed by the Bank of Russia, its main advantages and disadvantages.
\end{abstract}

\section{Introduction}

The Bank of Russia is not the discoverer in the issue of introducing a digital national currency. The idea of a digital currency issued by the Central Bank Digital Currency (CBDC) dates back at least a dozen years. Some countries have already put it into circulation, while the others are still piloting this concept.

For example, China began work on its own digital currency back in 2014; the pilot for its use was launched in 2017. The currency was piloted in different cities of the country: in southern Shenzhen, eastern Suzhou, midwestern Chengdu and northern Xunan. Civil servants and employees of state institutions of these cities received a small amount of their remuneration in digital currency, which could be spent in retail stores and restaurants.

Later, tests of a new type of currency in China took place several more times. They were organized according to a similar scheme [1]: vouchers totaling several million yuans were competed among residents, which could be spent in different online and offline stores. Each participant in the experiment received 200 yuans (\$30). Between 50,000 and 100,000 Chinese residents participated in each test [2]. The participants in the experiment needed to create a special account for DCEP transactions using their mobile phone number, and download the wallet application of one of the state banks in China. After registration, sellers and buyers could pay each other by scanning the QR codes generated by the application. On the balance check page, users were shown a portrait of Mao Zedong, which is presented on a 100 yuan banknote [3].

In October 2020, China published a bill, after the entry into force of which the country's digital currency will receive legal status. China plans to fully use it at the Olympic Games in 2022 in Beijing [4].

Transactions using cyber-yuan can be carried out without the Internet, and access to savings will not require a bank account, which about $20 \%$ of the country's adult population (about 225 million people) do not have, said China's state-owned television company CGTN, which also calls the transition to digital currency "a big step in the fight against poverty". According to the World Bank, about 1.7 billion people worldwide live without a bank account [2].

The Chinese side is not too willing to disclose the details of the pilot on the use of digital currencies. However, it is already clear that the People's Bank of China will be the holder of the records of the digital yuan database. At the same time, non-bank institutions will not be able to provide exchange services for customers, and the commercial banks of the PRC will be the discoverers. The payment system will be free of charge. The literature suggested that the digital yuan could become one of the leading trading currencies in the world, provided that the most powerful in the world and the most downloaded Internet platform today (Alibaba) is switched to it.

In China, the digital yuan is the same money, but in a different form, in Russia it is part of the state issue of currency.

Corresponding author: us@urallaw.ru 


\section{Results}

According to the proposed Concept, the digital ruble is an additional form of the Russian national currency, which will be issued by the Bank of Russia digitally and combines the properties of cash and cashless money. On the one hand, like cashless money, the digital ruble makes remote payments and settlements online possible. On the other hand - like cash, it can be used offline if you do not have access to the Internet. Like cash and cashless money, the digital ruble will perform all three functions of money, acting as a means of payment, a measure of value and a means of saving.

Besides, the digital ruble should be designed to provide reliable, safe, fast, convenient, affordable for every citizen (and not only) monetary settlements anywhere in Russia.

It is assumed that this currency will become available to all subjects of the economy - citizens, business, financial market participants, and the state. All three forms of the Russian ruble will be absolutely equivalent: as now 1 ruble in cash is equivalent to 1 non-cash ruble, and 1 digital ruble will be equivalent to each of them.

The Bank of Russia also plans to provide for the possibility of buying digital financial assets on the digital ruble, which the law defines as digital rights, including:

- cash claims;

- possibility to exercise rights on securities;

- right to participate in the capital of a non-public joint-stock company.

The bank draws attention to the fact that the digital ruble is radically different from cryptocurrencies, which do not have a single issuer, as well as consumer protection guarantees, their value is subject to serious fluctuations. In most countries, they cannot be used to pay for goods and services and, as a rule, they do not have a single institution that ensures the safety of such funds.

The digital ruble is a fiat currency, i.e. a currency which stability is ensured by the state in the person of the central bank, is its obligation, is implemented through digital technologies and has nothing to do with cryptocurrencies.

It is assumed that smart contracts will be an additional functionality of the digital ruble platform. A smart contract is a transaction that is executed automatically when a pre-defined condition is met by the parties.

Smart contracts will optimize the business processes associated with interaction between counterparties, as well as minimize the time and cost of the transaction. It is planned that customers will have the opportunity to independently use smart contracts previously created by financial organizations and verified by the Bank of Russia. The smart contract will contain information about the parties to the transaction, the amount and the terms of its execution. The smart contract will be registered on the digital ruble platform after it is signed by all parties to the transaction.
One of the additional options for using smart contracts may also be marking digital rubles, which allows setting conditions for their spending (for example, determine specific categories of goods/services that can be purchased with their help) and track the entire chain of marked digital rubles. At the same time, the implementation of smart contracts on the digital ruble platform does not limit financial organizations in the implementation of smart contracts in their own systems.

To ensure information security and cyber stability of the prototype platform of the digital ruble, it is planned to use the following approaches.

In terms of organizing user access to the digital ruble platform:

- customer interaction with the digital ruble platform will be carried out in secure channels through the bank application installed on the user's mobile device;

- user's access to the wallet on which his digital rubles are stored, as well as all user transactions with the digital ruble are carried out using a specialized software module of the Bank of Russia (hereinafter referred to as the BR Software Module) integrated with mobile applications of credit institutions;

- BR software module is being developed by the Bank of Russia and will provide APIs for developers of applications of credit institutions and will be used to:

- ensure safe interaction of the user with the bank;

- $\quad$ generate and store a cryptographic access key of a client of a credit institution to a digital wallet;

- $\quad$ sign orders on operations with digital rubles of the client;

- cryptographic protection of user interaction channels with the infrastructure of a credit institution (encryption) when using a mobile application of a credit institution is carried out using cryptographic information protection facility (hereinafter referred to as the CIPF) certified by the Russia's FSB security agency.

In terms of organizing access of a credit institution to the digital ruble platform:

- when accessing the digital ruble platform, "strict" two-way authentication of direct participants is carried out using keys certified by the Certification Center of the Bank of Russia (hereinafter referred to as the SC BR) through secure interaction channels implemented using the Russian FSB-certified CIPF.

In terms of ensuring data protection on the digital ruble platform:

- use of Russian FSB-certified CIPF to ensure the integrity and reliability of data on the Bank of Russia platform when signing transactions with the digital ruble;

- creation of digital rubles exclusively using the issue key of the Bank of Russia. The issue key of the Bank of Russia is registered in a special SC BR;

- application of a set of technological measures of information protection (logical control, structural control, duplication control, authorship control, etc.);

- in areas where the use of certified CIPF is not possible, special technological measures are provided to ensure the integrity of data for operations with the digital 
ruble;

- organization of control over the integrity of smart contracts and access rights to the possibility of their launch.

During the development of the digital ruble platform, special attention in terms of information security will be paid to ensuring operational reliability and cyber stability at all stages of the digital ruble life cycle.

In terms of confidentiality:

The digital ruble platform will ensure the confidentiality of information on customers' transactions and the protection of their personal data. Besides, the digital ruble settlements do not imply anonymity of payments. The procedures stipulated by the legislation on anti-money laundering/terrorism financing/financing and proliferation of weapons of mass destruction [6] will be implemented by financial organizations providing for the performance of client operations in the digital ruble. In this sense, the degree of confidentiality of transactions on the digital ruble platform will be ensured at a level not lower than the existing cashless payment mechanism.

The Concept [5] proposes two main models for the introduction of the digital ruble.

The first model will exist within a two-tier banking system. The Bank of Russia will open electronic wallets to banks, and banks, in turn, open such wallets to their customers for settlements in digital rubles. Much of the proposed model can be implemented on the basis of an existing settlement system.

The second main model assumes that the Bank of Russia itself opens and maintains digital wallets of customers - companies and individuals. At the same time, the Bank of Russia itself becomes a participant in the financial market, this is a fundamental change. Under this scheme, the Bank of Russia has the functions associated with maintaining customer accounts, which are now carried out by commercial banks, for example, debiting funds to executive accounts and many other similar problems.

It seems that if the second model is adopted as a working model, it would be logical to consider removing the supervisory function from the functions of the Bank of Russia and transferring it to other bodies. The advantages of this model are that it will be easy to ensure the labeling of money and the automated accounting of its target use, which is important when controlling the use of budget funds.

The concept of the digital ruble aroused great interest among the expert community, as well as among all participants in the financial market, including bankers and financiers of Russian corporations. After all, the introduction of the digital ruble will affect the interests of all participants in the financial market and lead to serious changes in the economy.

The opinions of financial market participants on the introduction of a new currency were quite different. Thus, commercial banks fear the loss of part of liabilities after their flow into digital rubles and part of commission costs, an increase in the cost of liabilities. For the representatives of small and medium-sized enterprises, this innovation may result in a decrease in the costs of servicing cashless settlements that they currently carry.

In any case, the digital ruble should supplement the money circulation and will be used simultaneously with cash rubles and funds of the population and enterprises in accounts in commercial banks. Citizens and enterprises, based on their needs, will be able to freely use money in any form from one form to another, i.e. freely transfer digital rubles into cash or place them in a bank account and back.

The analysis shows that the proposed concept has both advantages and disadvantages.

The advantages of introducing a digital ruble include:

1) possibility to speed up and simplify cashless settlements;

2) possibility to reduce the costs of companies working with cash;

3) possibility of a client to access the wallet through any financial institution in which he is served;

4) possibility of setting service rates no higher than in the express payment system;

5) possibility of conducting settlements in the absence of access to the Internet (offline mode);

6) providing a high level of reliability. Digital Ruble - commitment of the Bank of Russia;

7) expansion of innovative services and products in the financial market;

8) presence of unique numbers in digital rubles, due to which it will become easier for their user to restore their rights when they are stolen.

The disadvantages of the digital ruble are as follows.

First, when implementing it, it may be necessary to distribute the relevant software to the user environment. For citizens, perhaps access to digital currency will be implemented through applications in smartphones and computers, which may limit access to digital currency to a certain category of people.

Second, it will not be easy to organize the offline mode of operation of the digital ruble, to solve the problem of possible fraud. Without the implementation of the offline mode, the interest in its use will significantly decrease.

Third, there is a risk of concentration of all settlements in one place, i.e. any technical malfunction of the Bank of Russia system may lead to serious problems in settlements throughout the country.

Fourth, as can be seen from the description of digital currency models, the "Central Bank Platform or the CBDC Platform" (digital currency of the central bank) plays a large role in these models, but it is not clear what is meant by the platform in this case. The findings of the Association of Russian Banks (ARB) on the "Digital Ruble" report of the Bank of Russia states that "all details of the construction and functioning of the payment platform should be provided (who will be the platform operator, how the issue will be carried out, how and by whom the payment will be validated, how the digital ruble will be exchanged for other forms of money, etc.)" [7]. At the same time, "concealment" (or misunderstanding) of this aspect of the introduction of the digital ruble may lead to the fact (due to the peculiarities of some of their models of the digital ruble) 
that this platform will be positioned as a replacement for the existing banking system, which under certain conditions may have negative consequences for the economy [8].

Meanwhile, at this stage of the introduction of the digital ruble in Russia, all options for the development of technology are probabilistic. In many ways, the regulator itself will set the vector of development, which will take into account the interests of the banking community and payment operators in the first place. Most likely, the Bank of Russia will use the infrastructure it has already created as much as possible: national payment system, financial messaging system, fast payment system, and Masterchain platform.

One of the important reasons for the introduction of the digital ruble is the possibility of its use for international settlements, which are a means of delivering the profit obtained as a result of their conduct to the subjects of international transactions.

International trade practices have developed forms of settlements that differ depending on the degree of mutual trust of trading partners, as well as the role that banks are called upon to play in each particular case in settlements between the buyer and the seller [9].

Some countries carry out settlement and credit transactions in accordance with interbank agreements. These agreements provide general and technical rules for conducting settlement operations, determine measures to develop and deepen cooperation in this area, strengthen and improve settlement and credit relations.

Currently, the following forms of international settlements apply: documentary letter of credit, collection, bank transfer, as well as settlements using checks and bills of exchange.

Settlements of Russian enterprises and organizations with firms and organizations of CIS- and non-CIS countries are carried out in convertible currencies, in US dollars.

The importance of international settlements lies in the performance of a security function in relation to international transactions. With their help, capital, money and credit are quickly transferred within the global financial system. The conditions, rules and procedure for documenting settlements between participants engaged in foreign trade are determined by intergovernmental treaties and agreements, financial, economic and legislative institutions, and state authorities.

The conditions governing settlement relations between counterparties are one of the most important elements of foreign economic contracts. Choosing the form of settlements and formulating the details of their implementation is the most difficult part of the payment terms of the contract.

The advantages of using the digital ruble for international settlements are the ability to minimize sanctions risks, as well as partially evade international settlements in euros and US dollars.

Besides, a big advantage is the organization of settlements using digital currency without using the current system of correspondent bank accounts. With such a settlement system, the role of banks in international settlements is reduced, and, therefore, as already indicated, the sanction risks. As a result, the digital ruble can take from $20 \%$ to $40 \%$ in the total structure of the money supply.

A serious reason for the introduction of the digital ruble is the possibility of its use for international settlements with our counterparty countries, including India and China.

\section{Conclusion}

Deutsche Bank experts issued a large-scale report [4], in which they examined the pros and cons of digital currencies using the examples of pilot projects from China and Sweden. According to the report, the advantages include the speed and simplicity of transactions, digital currencies strengthen the growth of the economy, are able to minimize the number of illegal money transfers, and allow monitoring the movement of money as much as possible.

This decision, as follows from the report, will bring significant advantages to the government of countries that have introduced digital currency. Transparency of operations will inevitably lead to the impossibility of tax evasion. Sweden's digital currency is likely to have circulation throughout the European Union, the digital crown can be adopted not only in Sweden. According to the document, the consequences of the introduction of the digital yuan may be even more global. Experts predict that countries working with China will abandon SWIFT (Society for Worldwide Interbank Financial Channels) - an international interbank system for transmitting information and making payments.

This system allows financial institutions around the world sending and receiving information on financial transactions in a safe, standardized and reliable form. It was founded in 1973. Thus, 248 banks from 19 countries were its co-founders. SWIFT is headquartered in Belgium, near Brussels. SWIFT is a cooperative society created under Belgian law and belongs to its members. As of 2015, more than 11 thousand financial organizations in more than 200 countries of the world, including about 1,000 corporations, are SWIFT members. The average turnover is more than 30 million messages per day), and Russia is ranked among such countries.

Indeed, the digital ruble is an ambitious project of the Bank of Russia, which can accelerate and simplify cashless settlements, and is also designed to compete with foreign digital currencies and work offline. Moreover, it has all the prerequisites to become an alternative to SWIFT a few years later.

The Bank for International Settlements, which performs the function of a "Central Bank", conducted a study in 2019 [10], in which it noted that by the beginning of 2020 , more than $80 \%$ of Central Banks from 66 countries, which account for $90 \%$ of the world GDP, are actively developing their own CBDCs. At the same time, they also develop the so-called wholesale digital currencies (for settlements of ordinary legal entities and individuals; they are closest to cash 
settlements), and retail (for settlements between financial institutions; they are a kind of alternative to the money of the Central Bank on credit accounts).

According to this study, as of 2019, $15 \%$ of Central Banks studied the possibility of introducing wholesale digital currencies, 35\% - retail, while the rest of the world Central Banks are working on both options. For both developed and developing countries, CBDC is primarily an increase in payment security, the efficiency of domestic transfers, and the availability of financial services to the population.

The situation with COVID-19 has shown that the world is ready for the most serious changes. The introduction of digital currencies by individual countries at the first stage may lead to the creation of a single world digital currency in the future.

The business will be able to use digital currency in addition to cashless settlements with the state, counterparties, financial organizations, employees. This will make it possible to automate the control and settlement of contracts and transactions in financial markets with the help of smart contracts, which will ensure the objectivity and impartiality of their execution, thus leading to an increase in the efficiency of economic process management and in general will positively affect the level of competitiveness of our country in the context of the development of digital technologies.

However, in order to introduce an additional form of the Russian national currency into circulation, there is a need for detailed elaboration of issues of currency control and conversion of the digital ruble into other currencies, operational revision of the current legislation in order to determine the authority of the Bank of Russia to organize money circulation on the basis of the digital ruble, its powers as an operator of a digital platform, within the framework of which the digital ruble will circulate, the rights and obligations of participants in this digital platform, the rights of the Bank of Russia to carry out banking operations using the digital ruble not only with credit institutions, but also with legal entities and individuals, etc. (for example, changes that will protect information on transactions using the digital ruble as information constituting a banking secret).

Indeed, the use of the digital ruble for international settlements is possible only after checking the success of its use for servicing national settlement systems. The joint study by the Central Banks of the practical feasibility of digital currencies based on common technical standards and mass training events so that all participants in the financial market strive to use the digital ruble are particularly relevant.

\section{References}

1. M. Dulneva, The population of Beijing will be given $\$ 1.5$ million to test foreign digital currency. Retrieved from: https://www.forbes.ru/newsroom/finansy-iinvesticii/420667-naseleniyu-pekina-razdadut-15mln-dlya-testirovaniya.

2. J.T. Areddy, China Creates Its Own Digital Currency, a First for Major Economy. Retrieved from: https://www.wsj.com/articles/china-createsits-own-digital-currency-a-first-for-major-economy11617634118.

3. M. Dulneva, Population control and independence from the dollar: why China creates its digital currency. Retrieved from: https://www.forbes.ru/finansy-i-investicii/426079kontrol-za-naseleniem-i-nezavisimost-ot-dollarazachem-kitay-sozdaet.

4. O. Oshanina, Ruble turns into a figure. Why Russia needs a digital currency. Retrieved from: https://www.kommersant.ru/doc/4566287.

5. Official website of the Central Bank (Bank of Russia). The concept of the digital ruble. Retrieved from:

http://www.cbr.ru/content/document/file/120075/co ncept_08042021.pdf.

6. Federal Law No. 115-FZ "On Combating the Legalization (Laundering) of Proceeds from Crime and the Financing of Terrorism" of 07.07.2001 (SPS ConsultantPlus)

7. Official website of the Association of Russian Banks. Retrieved from: https://arb.ru/b2b/docs/pismo_arb_na_zapros_banka rossii_o_proekte-10443566.

8. A.V. Gabov, Digital ruble of the Central Bank as an object of civil rights, Current problems of Russian law, 4, 55-65 (2021)

9. T.A. Ivanova, International monetary settlements in foreign economic relations, Lawyer, 8, 50-53 (2020)

10. Bank for International Settlements (2020). Impending arrival - a sequel to the survey on central bank digital currency. Retrieved from: https://www.bis.org/publ/bppdf/bispap107.pdf. 